\title{
Marijuana Legalization: Still an Open Question?
}

Frederick F. Wang*, Ayman T. Bridgewater*, Michael P. Worden*

Marijuana, a well-studied drug in scientific field, now has been being enabled to be a legal recreational substance by some U.S. states that evoked a wide discussion on its potential effects on our future life. A majority of people hold negative points on this drug; most of them are scientists, educators, physicians, and parents who have kids. However, another huge party who positively advocates the pot legalization is the people like businessmen, retailers, planters, and drug users. Along with the recent approval for banks allowed to open accounts for marijuana business, as well as the vigorous appeal for the drug's legalization, can the science win over the battle? For the drug itself, we need objectively to evaluate its possible effects. Everything has two sides like a double-edged sword, if you take the yin, and the yang is also there, and then is vise versa. Maybe marijuana legalization for recreational use was an out and out wrong, and maybe it was a wise decision. Who knows? The only thing we can do today is let time tell us the answer.

\section{*: Editors-in-Chief, Editorial Office, Science Insights, Chapel Hill, NC 27510, USA \\ Email: editor-in-chief@bonoi.org}

Submitted: 26 January 2014 Revised: 03 February 2014

Accepted: 04 February 2014

How to Cite This Paper: Wang FF, Bridgewater AT, Worden MP. Marijuana legalization: Still an open question? Science Insights 2014;6(3):123-127.

Keywords: Marijuana - Legalization - Recreation - Effects - Science

$\mathrm{N}$

OTHING is impossible. Astounding news was released that the ever illegal marijuana has been approved for allowing people to legally purchase for recreational use. Yes, it is a reality. On January 01, 2014, Colorado became the first state in the USA to legalize marijuana deal, with follower Washington State to do the same. Currently, 20 states and the District of Columbia allow the use of marijuana for medical purposes. This signals the possibility that other states would imitate Colorado and Wash- ington to make a greater legalization of the drug.

For what purpose holding for legalizing marijuana, it is certain, at least in part, that the legalization will likely have both positive and negative consequences. Even though we cannot predict the possible effects of this groundbreaking change on public health and safety, the businessman now is seeking evidence for supporting the act. Once again, "the business of America is business" became true. From drugsters to marijuana venders, they all are happy for the win-win business; and from marijuana plant- ing to banking services, they all wish the pot could be removed from the Schedule 1 list of drugs in the Controlled Substance Act.

Colorado's action right now looks all going smoothly. It marked the first time that the drug could be sold commercially for nonmedical purpose. However the biggest concern of critics is whether the new policy will increase teen use or lead to marijuana trickling out of the state. We cannot foresee these; they may take months or years to assess. In further, what consequences of this policy would make on the society, economy, safety, 
science and life are still unclear. We can sense some kinds of change from the knowledge we have now that the marijuana use would increase in the near future and it would also increase other types of risks on the science view.

\section{Trend of Marijuana Use}

Of the tendency of the marijuana use from its legalization will depend, in large part, on how many people start using the drug once it becomes legal. Yes, it is almost certain that the shift from illegal sales to a market-based system could open the flood gates to new users.

According to the National Institute on Drug Abuse, over 30\% of Americans between the ages of 18 and 25 reported using marijuana in the past year of 2012. For 12- to 17year-olds, usage was nearly $14 \%$. The direct effect of the legalization will be only on the increase in these numbers: from a non-smoker to a smoker, and from a general user to a heavy user. Ever though the laws of the Colorado prohibit the sale of marijuana to minors and teenagers, it is dif- ficult to guarantee these two types of people will not be deterred totally. You know, we are social men, we communicate every day and are connected each other.

Legalization of recreational marijuana is a changing point, though the federal law still prohibits banks and credit card companies from processing pot business transactions, and this may all be about to change. Buying the weed from an authorized dispensary is legal in some states, but banking laws clearly have not caught up. Right now, the banking business is looking for exit to make the services available to this industry. An extra key factor is that the governors are keen to tap into the potential tax receipts from marijuana sales, which will lead banks to lend money to legitimate marijuana businesses, and to set up private equity firms that can provide start-up financing and capital to these businesses. In one such move, executives at High Times magazine have created the HT Growth Fund and aim to raise $\$ 100$ million fund for pot-related start-ups. All these worry now has become reality, US regulators on February 14, 2014 told banks that they can allow marijuana dealers to open accounts, as states around the country begin to legalize the drug for medical and in some cases even recreational use.

The estimating value of the legal marijuana is $\$ 1.4$ billion. While pot is a legitimate business, many marijuana customers still get their pot from their illicit dealers rather than from the legitimate dispensaries largely due to the high price of the legal weed from which there the business needs pay high sales and excise taxes. This is also the reason why a robust underground market still operates in many of the same areas where the weed sale was legalized.

Other states like Florida is ready to change the current drug situation by collecting voter signatures to put the proposal of "supporting medical marijuana constitutional amendment" to be balloted which means if the petition is approved by $60 \%$ of voters in November 2014, Florida would become the first southern U.S. state to approve marijuana for medical use, joining 20 other states (see Table 1).

\section{Table 1. Historical Records on Changes in Marijuana Laws in the U.S.*}

\begin{tabular}{|c|c|c|c|c|}
\hline Purpose & States & Action & Action Time & Laws \\
\hline \multirow{5}{*}{ Recreation } & Colorado & $\begin{array}{l}\text { Decriminalized recreational use } \\
\text { Recreational-use stores opened }\end{array}$ & $\begin{array}{l}2012 \\
2014\end{array}$ & Rules for growers, processors, retail sellers and testers of the drug \\
\hline & Washington & Decriminalized recreational use & 2012 & Rules for growers, processors, retail sellers and testers of the drug \\
\hline & California & & & \\
\hline & Alaska & Advocates of legalization & 2016 & \\
\hline & $\begin{array}{l}\text { Arizona } \\
\text { Oregon }\end{array}$ & & & \\
\hline \multirow{3}{*}{ Medicine } & California & Proposition 215 & 1996 & \multirow{3}{*}{$\begin{array}{l}\text { The first state to allow for the medical use of marijuana } \\
\text { Patients can grow their own pot, obtain it from a dispensary, or both }\end{array}$} \\
\hline & $\begin{array}{l}\text { Washington, D.C. } \\
+ \text { Another } 18 \text { states }\end{array}$ & & 2011 & \\
\hline & New York & In ready & & \\
\hline \multirow{5}{*}{$\begin{array}{l}\text { Personal } \\
\text { Cultivation }\end{array}$} & Hawaii & & & \multirow{3}{*}{ Allow at least some patients to grow limited quantities of marijuana for themselves } \\
\hline & Montana & & & \\
\hline & $\begin{array}{l}\text { Maine } \\
+ \text { Another } 10 \text { states }\end{array}$ & & & \\
\hline & Arizona & & & Require cultivation person to live at least 25 miles from a dispensary \\
\hline & Massachusetts & & & Limit it to those physically, financially or geographically encumbered from buying from a dispensary \\
\hline \multirow{4}{*}{ Dispensaries } & $\begin{array}{l}\text { Washington, D.C. } \\
+ \text { Another } 15 \text { states }\end{array}$ & Permit medical pot dispensaries & & Patients can obtain the drug \\
\hline & $\begin{array}{l}\text { Connecticut } \\
\text { Illinois } \\
\text { New Hampshire } \\
+ \text { Another } 4 \text { states }\end{array}$ & & \multirow[t]{3}{*}{2015} & Patients can obtain the drug \\
\hline & $\begin{array}{l}\text { Montana } \\
\text { Michigan }\end{array}$ & & & Have dispensaries operating within their borders \\
\hline & $\begin{array}{l}\text { Michigan } \\
\text { Washington }\end{array}$ & & & Some dispensaries grow their own pot, while others get it from state-licensed growers or from patients \\
\hline
\end{tabular}




\section{Consequences of In- creased Use}

What kinds of consequences would be resulted from the legalization sale of the drug? How much you know about the weed from the point of science? We all know that business is not for science, but science in contrast is for business well. The fact is that marijuana has several wellstudied effects on public health and safety. Currently, the public is largely misinformed concerning the health and behavioral effects of marijuana. In fact, science knows much about the drug, but people know little.

First of all, marijuana is a hallucinogenic drug, the major reason why a lot of people seeking it for recreation purpose. All its hallucination effects derive from the drug's role in the central nervous system (CNS). Therefore, bear in mind that marijuana is addictive. According to the National Institute for Drug Abuse, estimates suggest that one in nine users become addicted to marijuana. For people who start using as teenagers, this increases to one in six.

Before the drug became popular for its legalization, I just thought that marijuana is an addictive drug like heroin and lysergic acid diethylamide (LSD). However, the fact is not the same as I thought. It became one legalized drug you can get only if you want to. Although the marijuana dependence is not that life-threatening, it can lead to very serious adverse consequences for individuals in terms of their functioning in school, at work, and in relationships. Moreover, the cognition function can be adversely affected if the drug was compulsively used.

Second, teenagers, the future hope of the society, are in particular susceptible to the negative effects of marijuana because their brains are still developing. Can you believe one child has a high IQ point if he or she using the drug? Our governors, if you think your children could resist the temptation from their peers, and if you think your "wise" decision could

\section{Knowledge Box}

Current Scientific Knowledge about Marijuana: For marijuana, science can tell you something new from ample research evidence. OK, let science speak. We need weigh in and out the positive and negative effects of marijuana use for our life, health, learning, and relation.

$\square \quad$ Cannabis products can alleviate symptoms of depression, glaucoma, spasms, and nausea associated with cancer and AIDS.

$\square$ Cognitive impairment is one of the most important side effects associated with cannabis drug abuse, as well as the serious issue concerning the therapeutic use of cannabinoids.

$\square \quad$ Marijuana can impair brain development, memory and lung function, and lead to addiction.

$\square$ Pregnenolone, a naturally occurring hormone, acts as spontaneous defense in the brain against the high caused by marijuana and could be useful in preventing addiction through reducing the activity of a particular brain molecule called the type-1 cannabinoid receptor (CB1).

$\square \quad$ The high doses of cannabis raised the brain's level of pregnenolone, which blocked the harmful effects of THC, the psychoactive ingredient in marijuana, on the brain.

$\square$ In alcoholism, cocaine and heroin dependence, striatal dopamine D2/3 receptor is in low availability and the release in ventrostriatal dopamine is low. However, cannabis dependence is an exception among commonly abused drugs in that it is not associated with blunting of the dopamine system.

$\square$ Baclofen can reduce cannabis withdrawal symptoms and the subjective effects of cannabis.

$\square \quad$ Mothers' marijuana use is an important component of adolescent use, even after accounting for characteristics of the child and the intergenerational family context.

$\square \quad$ High frequency use of cannabis predicts a decreased satisfaction with life and one's own academic and professional achievement as well as an increased use of other substances.

Early cannabis use is associated with the occurrence and the severity of psychotic symptoms during cocaine intoxication.

$\square \quad$ Cannabis can increase risk of squamous cell carcinoma of the tongue, larynx, and possibly lung.

$\square \quad$ An earlier age of onset of schizophrenia has been identified as a poor prognostic indicator. Cannabis use is associated with an earlier age of onset of schizophrenia, and the gender difference in age of onset is reduced among cannabis smokers.

$\square \quad$ Marijuana-related problems are associated with marijuana use frequency. Concurrent alcohol use impacts the experience of negative consequences from marijuana use in young women. Discussions of marijuana use in young adults should consider the possible potentiating effects of alcohol use.

$\square \quad$ Overlapping genetic influences underlie the association between early-onset cannabis use and other illicit drug use as well as depression and suicide.

$\square \quad$ Nabiximols (Sativex) attenuates cannabis withdrawal symptoms and improved patient retention in treatment. In this situation, the placebo also was as effective as nabiximols in promoting long-term reductions in cannabis use following medication cessation.

$\square \quad$ The endocannabinoid system is widespread throughout the central nervous system and its CB1 plays a crucial role in preventing the neurotoxicity caused by activation of glutamate N-methyl-D-aspartate receptors (NMDARs). Indeed, it is the activity of NMDARs themselves that provides the demands on the endogenous cannabinoids in order to control their calcium currents.

$\square \quad$ Cannabinoid hyperemesis is a relatively rare but significant adverse effect of chronic marijuana use characterized by severe, cyclic nausea, vomiting, and abdominal pain and marked by compulsive hot-water bathing for temporary symptom relief.

$\square \quad$ The modulation of cholinergic activity by CB1 receptor activation is one mechanism that regulates the synthesis of plasticity-related proteins.

$\square \quad$ Cannabis use is common in patients with inflammatory bowel disease and subjectively improved pain and diarrheal symptoms. However, cannabis use was associated with higher risk of surgery in patients with Crohn's disease. 


\section{People's Voice}

Nearly $30 \%$ of students reported ever having used marijuana at college entry. Among students who had never used marijuana prior to college, $8.5 \%$ initiated use during freshman year. This means we need target substance abuse prevention programs on college campuses. Let's listen to the voice from people.

David Pearse from Tucson, Arizona Your editorial is generally informative and factual. However, it still manages to demonize pot with comments such as "problem users," "marijuana-related crime," "more violence" and increased "teenage use." There are no studies or other proof that merely smoking marijuana incites crime or violence. Violence with marijuana has only been driven by the profits from the illegal growing, distribution and sales of the drug. Further, there will be a reduction in pot use by teenagers because it will only be sold to adults.

George W. Iliff from Port St. Lucie, Florida

In the closing line of the editorial you say "better, then, to let Colorado go first, and watch what happens." When skiing avalanche chutes at A-Basin, it's the same principle-let the snowboarders go first and watch what happens.

Steve Juhan from Tucson, Arizona The shortsightedness of Colorado voters in legalizing the sale and use of marijuana astounds me. One consequence of this law that I have not seen discussed is the effective exclusion of what appears to be a growing portion of the younger generation from a major part of the job market. Colorado may have accepted pot smoking, but industry has not. One still has to pass a drug test to be considered for employment in most of the major industries, including natural resources, energy, manufacturing-and yes, even environmentaland failure to pass a drug test while employed can constitute grounds for banishment from the job site at best, or immediate dismissal. Since marijuana can be detected in the blood for several weeks, this is not the same as having a few drinks. It seems unlikely that safety managers will consider loosening strictures in the litigation-happy world we now live in, particularly in the wake of various incidents in recent years. Future job seekers from Colorado who are rejoicing today may be in for a major reality check when they are handed a plastic cup in their first new employee-orientation session. . help to pave your way to a promotion because of the sales taxes revenue, and if ....., that means you are irresponsible and disqualified for being to be leaders. Maybe you got appeal from some bad businessmen, or maybe you did not consult this to scientists for scientific view, or maybe you yourself are a drug user, no matter what kinds of reasons you had upon the marijuana legalization, this is really a terrible case that might change our world from the normal to the aberration.

Third, the legal use of marijuana would increase the number of people who drive while high. Do you think what would happen for these guys? Even though the precise correlation between marijuana use and traffic accidence is still unclear, its longterm effects on traffic safety are almost predictable. Being high and driving would increase the risk of accidents because of the drug can affect the driver's motor performance, perception, and concentration. It is not only dangerous for the drug-use drivers, but also for other drivers.

Fourth, from the point of the medical science, marijuana use during pregnancy could affect a baby's brain development by interfering with how brain cells are wired. Animal research showed that marijuana can interfere with the formation of connections between nerve cells in the cerebral cortex, the part of the brain responsible for higher thinking skills and forming memories. Furthermore, these effects of prenatal marijuana exposure could even last into adulthood. The drug could have direct effects, or it could sensitize the brain to future drug exposure or neuropsychiatric illnesses. Besides, prenatal cannabis disrupts synapses critical for higher order executive and cognitive function. Cumulating evidence showed that children exposed to marijuana in the womb may have an increased risk of showing cognitive effects, seeking out drugs, or having attention deficit disorder, anxiety or depression. As thus the pregnant women should avoid marijuana,

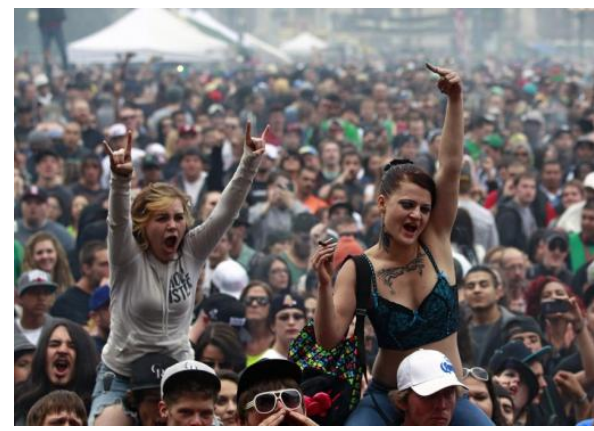

and if the pregnant has used the drug, they should be made aware of the potential impact on the brain development of their children.

Last but not the least, the consumption of marijuana also can increase the risk of heart attack and stroke for adults with cardiovascular disease and acute psychotic episodes in people with a history of schizophrenia.

\section{The Businessman's}

\section{View}

From the point of view of businessmen, there is no proof marijuana incites crime or violence. They appeal for the legalization and applaud for the action. Let us have a look at their contrast point: tens of thousands of Mexicans and South Americans have died due to the draconian drug laws that make hard drugs and marijuana illegal. Tobacco, which is legal, kills 440,000 people annually. Alcohol, another legal drug, kills another 88,000 yearly. Marijuana kills exactly nobody yearly. So why don't you go on a campaign to outlaw both tobacco and alcohol? Oh, right, we have already tried outlawing alcohol during the Prohibition era, and that was such a failure that the constitutional amendment outlawing alcohol had to be repealed by another constitutional amendment.

They thought legalize pot was a wise action. Yes, it is understandable that entrepreneurs, like water finding a path, will always figure out a way to respond to business opportunities. Fairness is one big issue they thought to marijuana. If it was justified for the cannabis, the smoking and alcohol also should be banned equally because in the 48 states that do not 


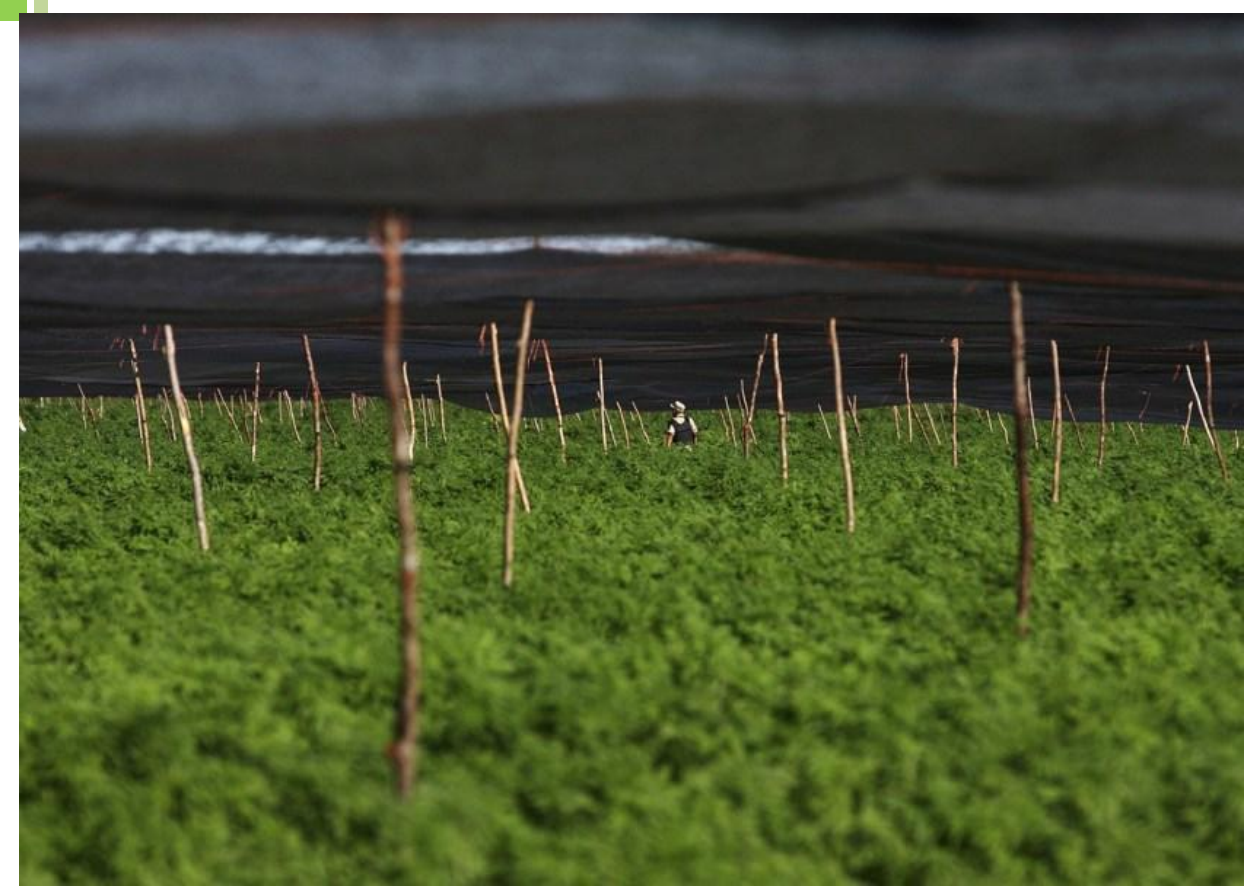

permit recreational use of marijuana, smoking tobacco, which causes cancer, is legal. In comparison, smoking weed, which is used to treat the symptoms of cancer treatments, is not. Moreover, some experts believe that alcohol, which is legal in virtually all parts of the United States, is more harmful than marijuana, which is illegal in almost all of the country. At first sight, all these description is reasonable. We all know one fact is that if you want to find supporting evidence for anything, surely you can.

Cultural attitudes, fairness, economics, and entrepreneurial behavior all point to extension of this trend toward legalization. Economic benefits from making pot legal have become one hot topic for policymakers. From them marijuana is a "money plant" that can bring back or offset the financial deficit. Entrepreneurs find and pursue market opportunities wherever they are. Making a business illegal doesn't get rid of the efforts of entrepreneurs to pursue it. For them, money is everything. We even can hear some strange and absurd argument concerning the pot legalization. They argued that by making pot legal, police can focus their attention on stopping more destructive illegal drugs like cocaine, heroin, and LSD, which are more likely to cause crime and health problems. That would help financially strapped states.

"Pursuing marijuana business will make you rich", some supporters for the legalization declared that it was an opportunity to become rich via getting in this business. It is difficult to describe the exuberance that pervades a new industry, particularly one that involves the cachet of a newly legalized drug like marijuana. Of the two dozen or so people I spoke with in the business, every last one of them was convinced that they were on the road to riches. How long will this opportunity last? That remains to be seen, but one thing is for certain: the countdown has begun.

The trend, whether you like it or not, toward fully legalized marijuana is here and it is likely here to stay. To the enterprising investor, they just thought everyday how can they get in on this potential money train. At the end of the day, despite the magnetic attraction of a new and burgeoning industry, most investors including the passive investors would be better off sticking to more traditional investment alternatives.

\section{What are We Facing?}

The journey is just beginning. The negative consequences, business opportunities, and worries about its legalization all need time to be seen.

The Seattle Police Department, grappling with how to handle legal marijuana, is considering whether offduty officers should be allowed to moonlight as security guards for the city's first recreational pot shops when they open later 2013. As the Denver Police Department to bar offduty officers from working for legal marijuana businesses, The Seattle department faces the same questions, just one of many issues law enforcement agencies are grappling with after Washington State and Colorado voted in 2012 to legalize recreational pot.

Like liquor, off-duty officers currently can provide security to it and grocery stores that sell alcohol because drinks are not consumed on the premises, but a police policy prohibits officers from working in bars or nightclubs where alcohol is consumed. The off-duty policy would eventually be amended to specifically address whether or not officers are allowed to work for marijuana retailers.

Another issue is that marijuana tourism will also get close scrutiny, with the potential for conflict as tourists may forgetfully bring back some souvenirs from the state that aren't legal in other states.

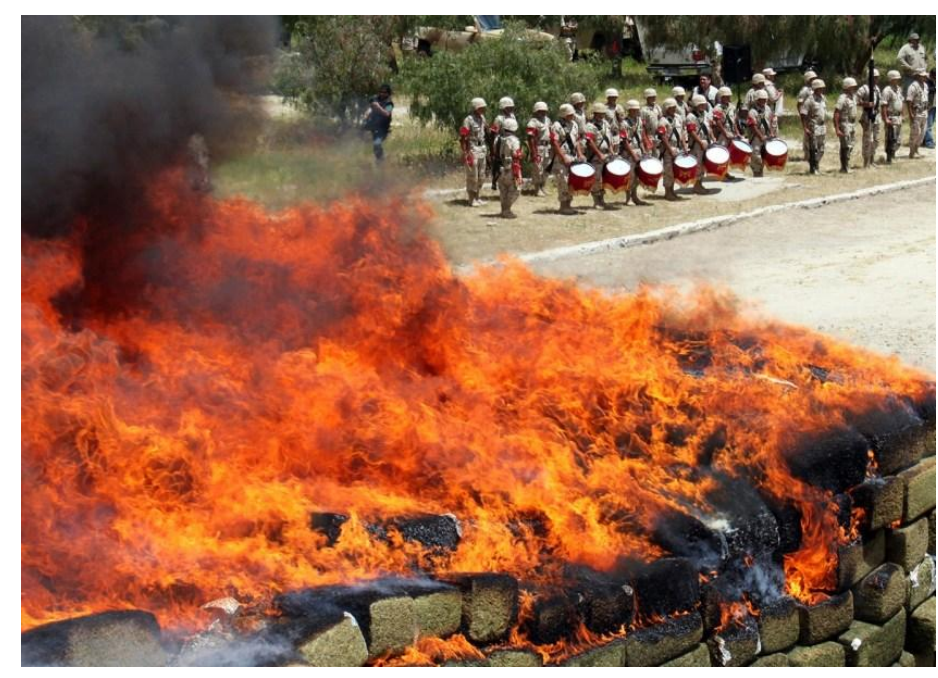

